\title{
水素化脱硫触媒の表面設計と活性サイト構造
}

\author{
岡本康昭・広光一郎・久保田岳志 \\ 島根大学総合理工学部 嶫690-8504 島根県松江市西川津町 1060
}

（2008 年 9 月 10 日受理）

\section{Surface Design for Hydrodesulfurization Catalysts and their Active Site Structure}

\author{
Yasuaki Окамото, Ichiro Hiromitsu and Takeshi KuвотA \\ Department of Material Science, Shimane University \\ 1060 Nishikawatsu, Matsue, Shimane 690-8504
}

(Received September 10, 2008)

\begin{abstract}
In order to get deeper insights into $\mathrm{Co}-\mathrm{MoS}_{2}$ hydrodesulfurization (HDS) catalysts, we tried to prepare surface designed Co-Mo HDS catalysts, in which the active sites, CoMoS, are selectively and fully formed, by means of a CVD technique using $\mathrm{Co}(\mathrm{CO})_{3} \mathrm{NO}$ as a precursor to Co sulfide. The CVD catalysts were characterized by XPS, XAFS, NO adsorption, and magnetic measurements. Thus CVD-Co/ $\mathrm{MoS}_{2}$ catalysts allow us to study the structure of CoMoS, the reaction mechanism of HDS, and the effects of additives and sulfidation conditions on HDS activity in terms of TOF. The structure of CoMoS is described as dinuclear Co sulfide clusters located on the edge of $\mathrm{MoS}_{2}$ particles. The electronic state of CoMoS and its TOF are determined by the interaction between $\mathrm{MoS}_{2}$ particles and the support.
\end{abstract}

KEYWORDS : hydrodesulfurization, Co-Mo catalysts, active site structure, XAFS, magnetic property of Co

\section{1.は じめに}

産地にも依存するが, 原油中には $0.05 〜 2.5 \%$ 程度の 硫黄が有機硫黄化合物として含まれている。この硫黄は 硫黄酸化物として酸性雨など環境污染の原因となるばか りでなく，ディーゼル機関では，軽油中の硫黄分が多い ほど内燃機関における粒子状物質（PM）の生成が多く なることが知られている。さらに, 硫黄分の存在は, NOx や PM の排出量を低減させる排気ガス浄化装置の 利用を妨げるため, 硫黄分の一層の低減が求められてい る $^{1,2)}$ 。日本では超深度脱硫触媒の開発により，2005 年 より世界に先駆けて, 硫黄分 $10 \mathrm{ppm}$ 以下のいわゆるサ ルファーフリー軽油およびガソリンが市販されている。 これら燃料油のサルファーフリー化を可能にし, 環境保 全に大きく貢献した超深度脱硫触媒の開発には, 燃料油 の特性, 水素化脱硫触媒の構造と触媒特性, 劣化に関す る分子レベルでのキャラクタリゼーションと理解が不可

E-mail : yokamoto@riko.shimane-u.ac.jp
欠であった。更なる高活性触媒の開発は, 環境保全のみ ならず，エネルギー・資源の有効利用の観点からも喫緊 の課題となっている。画期的な触媒開発のためには, 水 素化脱硫触媒の活性発現機構に関する詳細な知見が必要 である。ここでは, 水素化脱硫触媒の表面設計, 活性サ イト構造, 機能発現機構に関する我々の取り組みを中心 に述べ，また，最近の研究動向についても触れたい。

\section{2. 水素化脱硫反応と水素化脱硫触媒}

水素化脱硫反応（hydrodesulfurization, HDS）は, 有機 硫黄化合物の C-S 結合を水素存在下で切断し, 硫黄を 硫化水素 $\mathrm{H}_{2} \mathrm{~S}$ として取り除く反応である。例としてチ オフェンの HDS 反応を（1）式に示す。

$$
\left\langle{ }_{\mathrm{S}}+3 \mathrm{H}_{2} \longrightarrow \mathrm{H}_{2} \mathrm{~S}+\leadsto\right.
$$

水素化脱硫触媒として Co-Mo, Ni-Mo, Ni-W 二元系硫 化物触媒が主として工業的に用いられている ${ }^{1 \sim 3)}$ 。Co, Ni，Mo あるいはW 硫化物のみでは, ほとんど HDS 活 性を示さないが, 二元系にすることにより，それぞれの 
金属硫化物間に強い複合効果が発現する。この複合効果 は, Topsøe ら ${ }^{3)}$ の ${ }^{57} \mathrm{Co}$ メスバウアー発光分光法 (MES) やNO 吸着を用いた研究により, 層状化合物である $\mathrm{MoS}_{2}$ 粒子のエッジに Co が存在する新规な活性サイト の形成によることが明らかとなった。Topsøe らはこの ような $\mathrm{MoS}_{2}$ エッジと相互作用している Co 種を CoMoS (相/構造）と呼んでおり, 現在, CoMoS が HDS 触媒の 活性サイトとして一般に受け入れられている。さらに, Co 当たりの活性が異なる 2 種類の CoMoS（比較的低活 性な $\mathrm{CoMoS}$ (I) と約 2 倍程度高活性な $\mathrm{CoMoS}$ (II)）の存 在が明らかになっている。

実用触媒系では CoMoS を形成する Co 種以外にも Co 硫化物 $\left(\mathrm{Co}_{9} \mathrm{~S}_{8}\right)$ クラスターや担体と結合した $\mathrm{Co}$ 種 (通常用いられている $\mathrm{Al}_{2} \mathrm{O}_{3}$ 担体では, $\mathrm{CoAl}_{2} \mathrm{O}_{4}$ に似た 局所構造をもつ $\mathrm{Co}^{2+}$ 種) 等が共存し, Fig. 1 に示すよ うに複雑な表面構造をもつことが明らかになってい る ${ }^{3)}$ 。 Ni-Mo, Ni-W 触媒に関しても同様である。触媒の 活性は, 活性サイトの数とそのサイト当たりの活性 （Turnover Frequency；TOF）で決まることを考慮すると， 触媒開発においても活性サイトに関する情報を，触媒調 製パラメータの関数として得ることが非常に重要であ る。さらに，活性サイト構造抢よびそのサイトへの反応 物, 被毒物質の吸着, 活性サイトでの反応の微視的機構 に関する詳細な知見により，種々触媒作用が合理的に説 明可能になると考えられる。しかし, 実用触媒系の複雑 性を考えると, MES など特殊な手法を用いることなし に，このような情報を得ることは容易ではない。

水素化脱硫触媒は，通常 XPS，TEM，NO あるいは $\mathrm{O}_{2}$ 分子の吸着量, NO 吸着の FTIR, 昇温硫化, XAFS など種々の手法を用いてキャラクタリゼーションされて

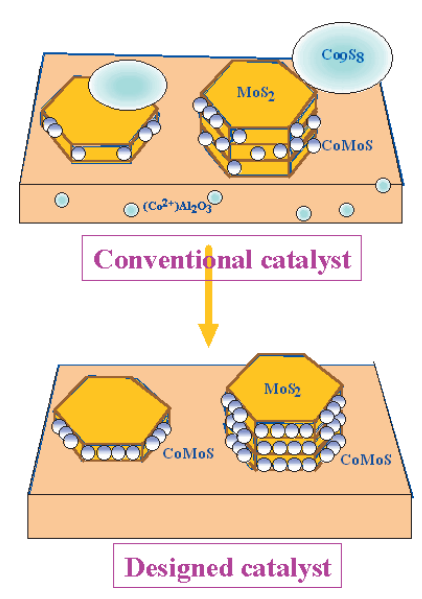

Fig. 1. (color online). Surface structure models of a conventional HDS catalyst and the designed catalyst. ${ }^{7)}$
きた。しかし，Fig. 1 に示すように実用触媒系では，活 性種に加え種々の化学種が共存する。また，担体は多く の場合絶縁体であり, 種々の電子分光法の情報も不明暸 となる。このような状況下では，それぞれのキャラク夕 リゼーション手法から得られる情報さえ不明確なものと ならざるを得ない。実用触媒系のもつこのような問題点 を「モデル触媒」の構築により克服し，より梁く水素化 脱硫触媒を理解しようとする試みがなされつつある ${ }^{4,5)}$ 。 ここでは, 水素化脱硫触媒の表面設計と活性サイト構 造, 水素化脱硫触媒機能の発現機構を中心に述べた $\left({ }^{6,7)}\right.$ 。

\section{3. 高活性 Co-Mo 水素化脱硫触媒の表面設計}

Fig. 1 に示したように，実用触媒系では全ての Co が $\mathrm{CoMoS}$ を形成するという保証はない。このことが害用 触媒系の解析を困難にしてきた。もし，触媒に含まれる Co が CoMoS のみとして存在する触媒の表面設計がで きれば，活性サイト構造の解析と HDS 反応機構, TOF とその触媒調製因子依存性など, 触媒化学的に重要な知 見が得られ，合理的な触媒設計へと展開することができ るであろうう。我々は, CoMoS を選択的に活性種として もつ, Fig. 1 に示す触媒の表面設計を目指し, $\mathrm{Co}(\mathrm{CO}){ }_{3} \mathrm{NO}$ の CVD (Chemical Vapor Deposition) 法を 試みた。このような触媒系をここでは「CVD 触媒」と 呼ぶことにする。

まず予備硫化処理により担持 $\mathrm{MoS}_{2}$ 触媒を調製し，そ れに $\mathrm{Co}(\mathrm{CO}){ }_{3} \mathrm{NO}$ を用いた CVD 法により $\mathrm{Co}$ を導入後 再硫化した触媒，CVD-Co/MoS 2 を調製した ${ }^{8,9)}$ 。CVD$\mathrm{Co} / \mathrm{MoS}_{2} / \mathrm{Al}_{2} \mathrm{O}_{3}$ 触媒についてXPS 測定の結果を Fig. 2 に示す ${ }^{8)}$ 。CVD 触媒では, $C o 2 \mathrm{p}_{3 / 2}$ の BE は $\mathrm{Co}_{9} \mathrm{~S}_{8}$ クラ

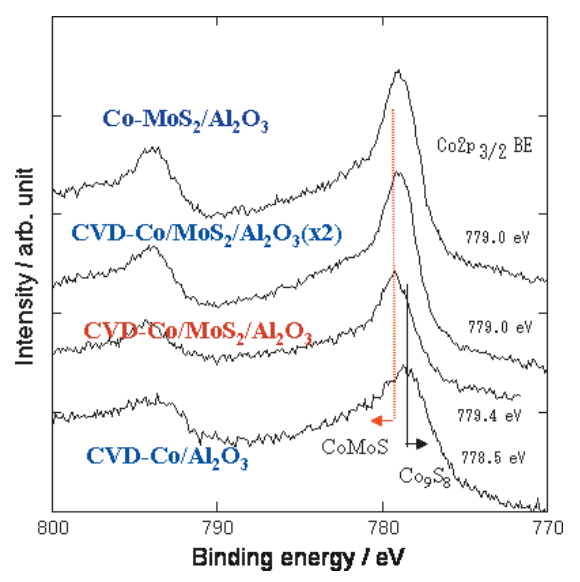

Fig. 2. (color online). XP spectra of the Co2p level for CVD$\mathrm{Co} / \mathrm{Al}_{2} \mathrm{O}_{3}, \mathrm{CVD}-\mathrm{Co} / \mathrm{MoS}_{2} / \mathrm{Al}_{2} \mathrm{O}_{3}, \mathrm{CVD}-\mathrm{Co} / \mathrm{MoS}_{2} /$ $\mathrm{Al}_{2} \mathrm{O}_{3}$ after the second CVD and sulfidation, and a Co- $\mathrm{MoS}_{2} / \mathrm{Al}_{2} \mathrm{O}_{3}$ impregnation catalyst. ${ }^{8)}$ 
スターに比較し $0.8 \sim 0.9 \mathrm{eV}$ 高く, Co 硫化物クラスター とは異なる Co 種の生成が明らかである。また, BE は CoMoS による值と一致した。XPS の結果は, CVD 法で 導入固定化された Co が $\mathrm{MoS}_{2}$ 粒子と選択的に相互作用 していることを示している。Co K-吸収端 XANES の結 果も Co 硫化物クラスター以外の新たな Co 種の生成を 支持した9)。さらに, CVD 法により固定化された Co 量 $(\mathrm{Co} / \mathrm{Mo})$ と $\mathrm{MoS}_{2}$ 触媒における $\mathrm{NO}$ 吸着量 (NO/Mo) 間に比例関係が見られた ${ }^{8)}$ 。 $\mathrm{NO}$ 分子は, $\mathrm{MoS}_{2}$ エッジサ イトに選択的に吸着することを考慮すると, CVD 法で 導入された Co は $\mathrm{MoS}_{2}$ エッジと相互作用をしていると 結論される。このことは, CVD 法を用いることにより, 選択的に CoMoS を調製できることを示している ${ }^{8,9)}$ 。

Fig. 3 に示すように, (1) 式に示すチオフェンの $\mathrm{HDS}$ 活性は, $\mathrm{MoS}_{2} / \mathrm{Al}_{2} \mathrm{O}_{3}$ に CVD 法で Co を導入する ことにより大きく増大し, Co-Mo 硫化物間に強い複合 効果が見られる ${ }^{8,10)}$ 。しかし，このように調製された $\mathrm{CVD}-\mathrm{Co} / \mathrm{MoS}_{2} / \mathrm{Al}_{2} \mathrm{O}_{3}$ に, 再度 CVD 法を用いて Co を導 入しても HDS 活性は増加しない。一方, Co 量は約 2 倍 に増えた。このことは, 本実験条件下では, 一度の CVD 操作で CoMoS を形成できる $\mathrm{MoS}_{2}$ エッジを完全に CoMoS で被覆し, CoMoS の量すなわち, 活性サイトの 数を最大にできることがわかった。また，すでにCo$\mathrm{MoS}$ を形成する Co と結合している $\mathrm{MoS}_{2}$ エッジサイト は, CVD 法でさらにCo を添加しても, その Co は硫化 処理後 Co 硫化物クラスターに変化した9)。このことは, Fig. 2 の XPS スペクトルで Co2 $\mathrm{p}_{3 / 2}$ 準位の BE が低下す ることと一致する ${ }^{8)}$ 。さらに, $\mathrm{CVD}-\mathrm{Co} / \mathrm{MoS}_{2} / \mathrm{Al}_{2} \mathrm{O}_{3}$ に 吸着したNO プローブ分子の FTIR スペクトルは, Co サイトに吸着した NO によるダブレットピークのみを与 え, $\mathrm{MoS}_{2}$ エッジが実際 CoMoS で被覆されていること

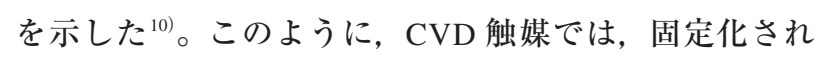

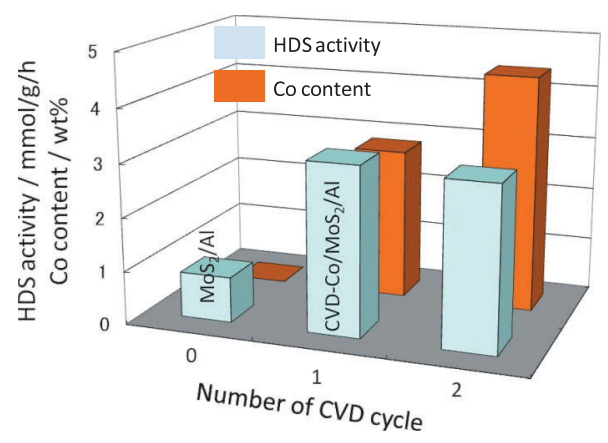

Fig. 3. (color online). Effects of the number of the CVD cycle on the thiophene HDS activity (front bars) and the amount of Co anchored (back bars) for CVD-Co/ $\mathrm{MoS}_{2} / \mathrm{Al}_{2} \mathrm{O}_{3}$.
た Co は選択的に CoMoS を形成し，その量が活性サイ トである CoMos の量に対応しており, 種々の現象を CoMoS の量および TOF で議論できる可能性を示してい る。

以上の結果は, Fig. 1 に示した水素化脱硫（HDS）触 媒の表面設計が CVD 法で可能であることを示してい る。さらに, CVD-Co/MoS 2 触媒では CoMoS 量が最大 となっており, 最大活性を示す触媒の表面設計でもある ことは, 注目すべきである7)。このことを利用して HDS 触媒のユニークなキャラクタリゼーションが可能となる が, 文献6,7,11,12)を参照されたい。

\section{CoMoS 構造と水素化脱硫反応機構}

活性サイトである CoMoS の（局所）構造は, 複合効 果発現機構解明との関連で, 多くの研究者によりXAFS を中心として検討されてきた。Bouwens ら ${ }^{13,14)}$ は, 活性 炭担持 Co-Mo 硫化物触媒について Mo および Co K-吸収 端 EXAFS を用いて解析した。触媒は, CoMoS が選択 的に生成すると期待されるキレート剤を添加して調製さ れた。フーリエ変換に Co-Moによるピークが見られ, $\mathrm{Co}$ が $\mathrm{MoS}_{2}$ と直接結合していることを示している。CoMo 原子間距離は, $0.28 \pm 0.01 \mathrm{~nm}$ であった。Co-Co 間の 寄与は見られず, Co は $\mathrm{MoS}_{2}$ エッジ上で原子状に高分 散していると推定された。Co-S $(0.221 〜 0.222 \mathrm{~nm})$ お よび Co-Mo 原子間距離は，それぞれ Mo-S (0.241 nm) および Mo-Mo $(0.316 \mathrm{~nm})$ 原子間距離より短いこと, また，それぞれの配位数（ $\left.\mathrm{N}_{\mathrm{Co}-\mathrm{S}}=6.2, \mathrm{~N}_{\mathrm{Co}-\mathrm{Mo}}=2.0\right)$ を考 慮して, CoMoS の活性構造では, $\mathrm{MoS}_{2}$ エッジの硫黄 4 原子と結合した Co に硫黄 1 原子が配位した 4 角錐型の 局所構造をもち, 原子状に高分散していると結論され た。Coの局所構造は, 反応中 5-6 配位の間で変化する と推定されている。Niemann ら ${ }^{15)}$ およびLouwers と Prins ${ }^{16)}$ は, XANES および EXAFS の結果から NiMoS に おける Ni の局所構造も同様であると結論している。後 者のグループは, $\mathrm{Ni}_{-} \mathrm{WS}_{2}$ 触媒の活性サイトである NiWS についても同様な結論を得た ${ }^{17)}$ 。

Bouwens ら ${ }^{18)}$ は, さらに $\operatorname{CoMoS}(\mathrm{I})$ および $\operatorname{CoMoS}$ (II) の構造, および担体効果について XAFS, XPS, MES を 用いて詳細に検討した。 $\mathrm{Al}_{2} \mathrm{O}_{3}$ 担持の $\mathrm{CoMoS}$ (I) では, $\mathrm{MoS}_{2}$ 粒子は単分子層を形成しており (XPS), Co-S 配 位数は 5 である。一方, $\mathrm{Al}_{2} \mathrm{O}_{3}$ 担持および $\mathrm{SiO}_{2}$ 担持 $\mathrm{Co}-$ $\operatorname{MoS}(\mathrm{II})$ では, $\mathrm{MoS}_{2}$ は数層程度の多層構造を形成して おり (XPS), 一部の Co は硫黄 5 配位, 他は 6 配位で ある。さらに, 活性炭 (C) 担持の CoMoS (II) では Co-S の配位数は 6 である。Co-Mo 配位数も担体および $\mathrm{CoMoS}$ の種類に依存し, $\mathrm{CoMoS}(\mathrm{I}) / \mathrm{Al}_{2} \mathrm{O}_{3}$ では $1, \mathrm{Co}-$ 
$\operatorname{MoS}(\mathrm{II}) / \mathrm{C}$ では 2 であり，他はその中間の值であると 報告されている。しかし, これらの構造は, 他の方法で は確認されておらず，検討の余地が残されている。

我々は, CVD 法を用いると CoMoS が選択的に調製で きることを利用し, Co の磁気的性質を用いて, CoMoS 構造について新たな知見を得ようとした ${ }^{19)}$ 。CVD-Co/ $\mathrm{MoS}_{2} / \mathrm{Al}_{2} \mathrm{O}_{3}$ について, Co の磁化率 $\chi$ の測定結果を Fig. 4 に示す。磁化率の温度依存性は, Co が反強磁性的性 質をもつことを示しており, 硫化 Co 間に磁気的相互作 用が存在することを示している。層状構造をもつ $\mathrm{MoS}_{2}$ のエッジに存在する Co は, 一次元鎖状化合物と見做す ことができる。硫黄を配位子としてもつため, 強い配位 子場にある $\mathrm{Co}^{2+}\left(3 \mathrm{~d}^{7}\right)$ イオンであることを考虑すると， 反強磁性的挙動から偶数個の Co イオンが相互作用をし ていると推定される。 $\mathrm{MoS}_{2}$ 粒子のサイズ（1～5 nm) を考慮し, そのような最小単位である Co 硫化物のダイ マーを仮定すると, Co の磁化率 $\chi$ は（2）式で表すこ とができる ${ }^{20)}$

$$
\chi=\alpha N_{\mathrm{A}} g^{2} \mu_{\mathrm{B}}^{2} / \mathrm{k}_{\mathrm{B}} T\left[3+\exp \left(-2 J / k_{\mathrm{B}} T\right)\right]
$$

ここで, $J$ は $H=-2 J S_{1} \cdot S_{2}$ で定義される磁気的相互作 用の大きさを表し， $\alpha$ は CoMoS を形成するCo の割合 である。Fig. 4 に示すように, 実験結果は, (2) 式で シミュレーションできることがわかった ${ }^{19)}$ このこと は, CoMos を形成する Co は, $\mathrm{MoS}_{2}$ エッジで Co-S-Co 結合をもつダイマーとして存在することを示唆してい る。

この点をさらに明らかにするため, Co K-吸収端 EXAFS の詳細な解析を行った ${ }^{21)}$ 。Fig. 5 に $k^{3} \chi(k)$ のフー リ工変換を示す。 $\mathrm{Ni}$ などの不純物もなく, $k$ の大きい範 囲まで解析できるため, フーリエ変換の各ピークは非常 によく分離しており, Co-S, Co-Mo に加え Co-Co によ

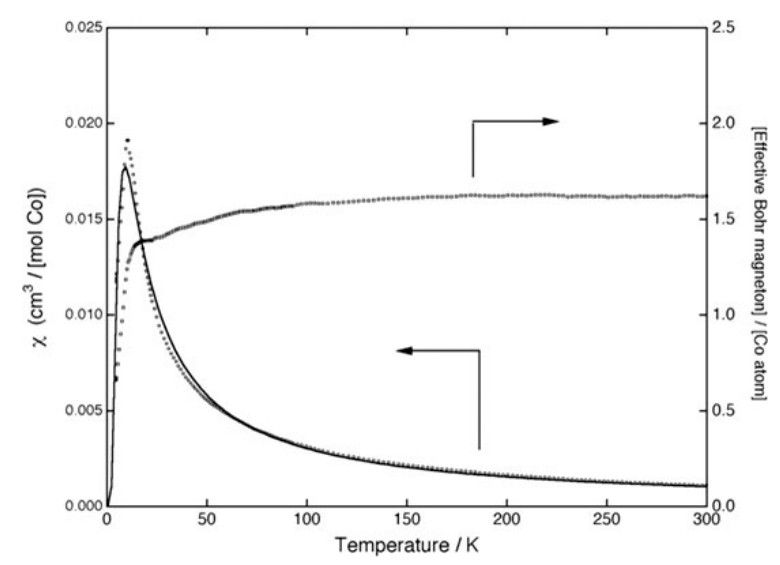

Fig. 4. Magnetic susceptibility $(\chi)$ and magnetic moment of $\mathrm{Co}$ as a function of temperature for CVD-Co/ $\mathrm{MoS}_{2} /$ $\mathrm{Al}_{2} \mathrm{O}_{3}{ }^{19)}$
るピークも明瞭に観察されることがわかる。Fig. 5 のフ ーリエ変換の解析により, 磁化率の測定結果から予測さ れるように, CoMoS は Co-S-Co 架橋結合をもつ Co ダ イマー構造をもつことが明らかとなった。CoMoSへの $\mathrm{NO}$ 吸着特性 $\left((\mathrm{NO})_{2} / \mathrm{Co}=0.5\right)^{19,22)}$ もダイマー構造に基 づき容易に理解される。Fig. 6 に推定される CoMoS 構 造を示す ${ }^{21)}$ 。

$\mathrm{MoS}_{2}$ 構造には, 結晶学的にいわゆるMoエッジ （1010）と S エッジ（1010）が存在する。EXAFS の結果 からは, Co 原子の存在するエッジを特定できない ${ }^{21)}$ 。 Lauritsen ら ${ }^{23)}$ は, Co- $\mathrm{MoS}_{2} / \mathrm{Au}(111)$ クラスターの STM による観察結果から, Co は S エッジにしか存在しない と推定している。しかし, Co は $\mathrm{MoS}_{2}$ の Moエッジに

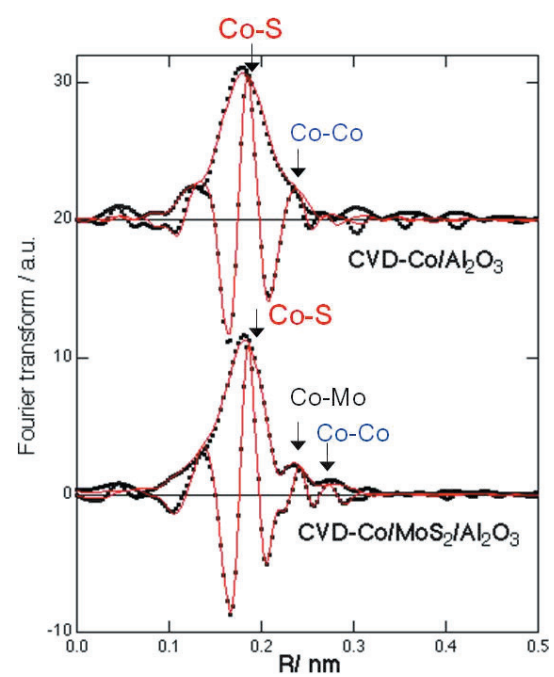

Fig. 5. (color online). Fourier transforms of $\mathrm{k}^{3} \chi(\mathrm{k}) \mathrm{Co} \mathrm{K}$ edge EXAFS oscillations for CVD-Co/ $\mathrm{Al}_{2} \mathrm{O}_{3}$ and $\mathrm{CVD}-\mathrm{Co} / \mathrm{MoS}_{2} / \mathrm{Al}_{2} \mathrm{O}_{3}{ }^{21}{ }^{21}$

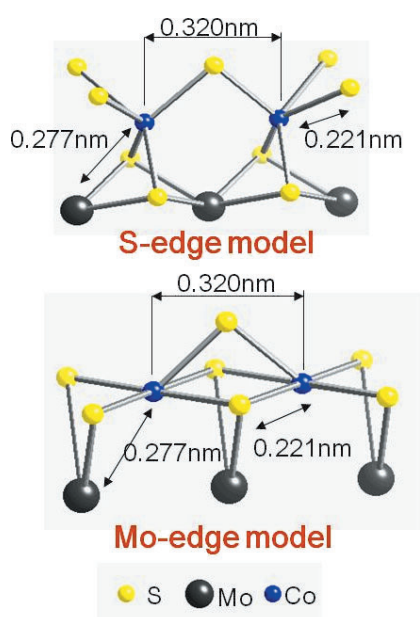

Fig. 6. (color online). Proposed structures of CoMoS on Sedge and Mo edge. ${ }^{21)}$ 


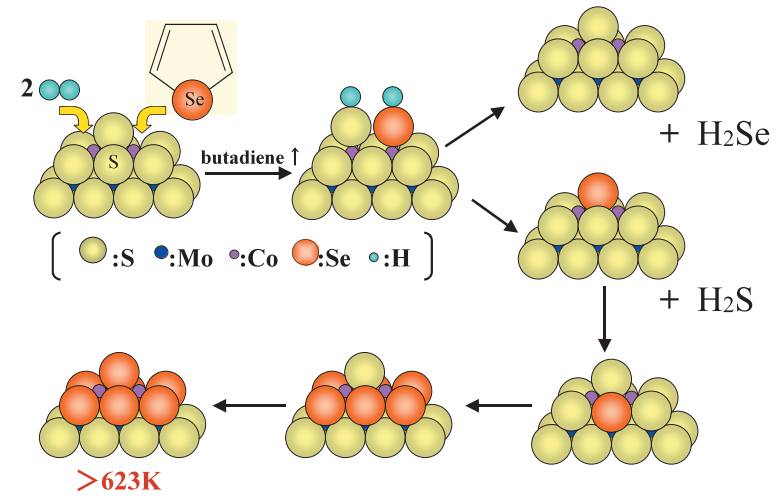

Fig. 7. (color online). Sulfur-selenium atom exchange during the hydrode-selenium reaction of selenophene over CVD-Co/ $\mathrm{MoS}_{2} / \mathrm{Al}_{2} \mathrm{O}_{3}{ }^{26)}$

存在することを示唆する DFT 計算の結果も報告されて いる ${ }^{24)}$ 。

活性サイト CoMoS で HDS 反応が起こる時の, 硫黄 の挙動を通して CoMoS の構造, 反応機構などを推定し ようとした ${ }^{25,26)}$ 。チオフェンの硫黄がセレンで置き換わ った化合物セレノフェンを用いて, Co-Mo 硫化物触媒 で水素化脱セレン反応（HDSe）を行った。反応初期で は, 触媒の S が Se に置き換わる S-Se 交換反応により, $\mathrm{H}_{2} \mathrm{~S}$ が生成するとともにセレンが触媒に取り込まれた。 Se および Co K-吸収端 EXAFS を測定することにより Se の取り込み口, 触媒内部での動きを推察することができ る $^{26)}$ 。反応の進行に伴い Co-S 配位数が減少し, 逆に Co-Se 配位数が増加し, CoMoS を形成する Co と結合し た硫黄がセレンで置き換わって行く様子を捉えることが できた。この結果は, Fig. 6 に示す CoMoS ダイマー構 造に基づき, Co の局所構造変化を矛盾なく説明できる ことが明らかとなった。Moエッジの CoMoS について $\mathrm{S}-\mathrm{Se}$ 交換反応の挙動を Fig. 7 に示した ${ }^{26)}$ 。

\section{5. $\operatorname{CoMoS}$ の比活性}

活性サイト CoMoS には, 比活性の異なる 2 種類, $\operatorname{CoMoS}(\mathrm{I}), \operatorname{CoMoS}(\mathrm{II})$ があることが知られている ${ }^{3)}$ 。 その生成理由を明らかにすることは, Co-Mo 間の複合 効果発現機構についての知見が得られるだけでなく, 高 活性触媒の開発にも有用である。CVD-Co/ $\mathrm{MoS}_{2} / \mathrm{SiO}_{2}$ 触媒でのチオフェン HDS 反応の TOF の予備硫化温度依 存性を検討した ${ }^{7,27)}$ 。TOF は硫化温度の上昇とともに増 加し, $873 \mathrm{~K}$ 以上の硫化で一定值となった。その $\mathrm{TOF}$ は, $\mathrm{CoMoS}$ (I) の活性サイトをもつ CVD-Co/ $\mathrm{MoS}_{2} / \mathrm{Al}_{2} \mathrm{O}_{3}$ での TOF の約 2 倍であり, $873 \mathrm{~K}$ 以上での硫化処理 により $\operatorname{CoMoS}(\mathrm{II})$ が生成することを示している。 $\mathrm{MoO}_{3} / \mathrm{SiO}_{2}$ の硫化挙動を昇温硫化法を用いて検討した
ところ，通常の硫化温度である $673 \mathrm{~K}$ では $\mathrm{Mo}$ の $\mathrm{MoS}_{2}$ への硫化が不十分であり, $873 \mathrm{~K}$ 以上ではじめて完全硫 化されることが明らかとなった。完全硫化により $\mathrm{MoS}_{2}$ 粒子と担体間の相互作用 (Si-O-MoS 2 など）が消失し, $\mathrm{MoS}_{2}$ 粒子の電子状態が変化し, エッジに存在する Co の活性に影響を与えるためと推定される。Hinnemann ら ${ }^{28)}$ は, Mo-O-Al 結合の存在により Mo-S 結合エネルギ 一が増加し, HDS 反応活性の低下に繋がることを DFT 計算から推定している。

$\operatorname{CoMoS}(\mathrm{II})$ の生成は, 担体の化学修飾によっても達 成できる。CVD-Co/ $\mathrm{MoS}_{2} / \mathrm{Al}_{2} \mathrm{O}_{3}$ では, $\mathrm{Al}-\mathrm{O}-\mathrm{MoS}_{2}$ 間の 強い相互作用のため $\operatorname{CoMoS}(\mathrm{I})$ が $673 \mathrm{~K}$ での硫化処理に より形成される。 $\mathrm{Al}_{2} \mathrm{O}_{3}$ に $\mathrm{B}_{2} \mathrm{O}_{3}$ を添加した担体に担持 した CVD-Co/ $\mathrm{MoS}_{2} / \mathrm{B}_{2} \mathrm{O}_{3}-\mathrm{Al}_{2} \mathrm{O}_{3}$ 触媒では, ボロンの添 加に伴い TOF は上昇し, $1.2 \mathrm{wt} \%$ B 以上で一定となっ た ${ }^{29)}$ 。ボロンの添加により Mo と非常に強く相互作用す る塩基性表面水酸基が Al-O-B 結合の生成により除か れ, Moがより容易に硫化される。その結果, $\mathrm{MoS}_{2}$ 粒 子と担体間の相互作用が弱くなり CoMoS の TOF は上 昇する ${ }^{30,31)}$ 。リンの添加も同様な効果があることが明ら かになっている ${ }^{32,33)}$ 。 $\mathrm{SiO}_{2}, \mathrm{~B}_{2} \mathrm{O}_{3}-\mathrm{Al}_{2} \mathrm{O}_{3}, \mathrm{Al}_{2} \mathrm{O}_{3}$ 担持触 媒における $\mathrm{CoMoS}$ の TOF と反強磁性パラメー夕 ( との間に直線関係が見出された ${ }^{34)}$ 。CoMoS の TOF と担 持 $\mathrm{MoS}_{2}$ の $\mathrm{TOF}$ 間にパラレルな関係があることを考虑す ると ${ }^{7,29)}$, 担体と $\mathrm{MoS}_{2}$ 間の相互作用 (Mo-O-Al/B/Si) により CoMoS 相の電子状態が影響を受け, TOF が変化 することを示唆している。

\section{6.おわりに}

ますます高活性, 高選択性, 高耐劣化性をもつ脱硫触 媒の開発が望まれている。今後, 工業触媒の開発は, 活 性サイトの数, 活性サイト当たりの活性, 活性サイト構 造, 反応機構に関する知見および, それに基づく表面設 計と開発指針，精密に制御された触媒調製化学なしには 行えない程ますます高度になっていく。 $\mathrm{Co}(\mathrm{CO})_{3} \mathrm{NO}$ を 用いる表面設計は, それらの知見を得る一つの有効な手 法となると期待される。理論化学や in situ 分光法の発 展, STM など表面科学的手法の適用 ${ }^{5,23)}$, 多元機能触媒 作用のより深い理解とも相まって, 水素化脱硫触媒に関 する全貌が明らかになり, また, さらなる高機能水素化 脱硫触媒の合理的開発も可能となることを期待してい る。

\section{文献}

1) 藤川貴志 : 触媒 44, 345 (2002).

2) 瀬川幸一 : 触媒 48, 228 (2006). 
3) H. Topsøe, B.S. Clausen and F.E. Massoth : "Catalysis Science and Technology”, ed. by J.R. Anderson and M. Boudard (Springer, Berlin, 1996) Vol. 11.

4) 岡本康昭: ペトロテック 27, 34 (2004).

5) 岡本康昭: 触媒 $\mathbf{5 0 ,} 28$ (2008).

6) 岡本康昭 : 化学工業 58,489 (2007).

7) Y. Okamoto : Catal. Today 132, 9 (2008).

8) Y. Okamoto, K. Ochiai, M. Kawano, K. Kobayashi and T. Kubota : Appl. Catal. A 226, 115 (2002).

9) Y. Okamoto, S. Ishihara, M. Kawano, M. Satoh and T. Kubota : J. Catal. 217, 12 (2003).

10) Y. Okamoto and T. Kubota : Catal. Today 86, 31 (2003).

11) Y. Okamoto, K. Ochiai, M. Kawano and T. Kubota : J. Catal. 222, 143 (2004).

12) Usman, T. Kubota and Y. Okamoto : Ind. Eng. Chem. Res. 45, 3537 (2006).

13) S.M.A.M. Bouwens, R. Prins, V.H.J. de Beer and D.C. Koningsberger : J. Phys. Chem. 94, 3711 (1990).

14) S.M.A.M. Bouwens, J.A.R. van Veen, D.C. Koningsberger, V.H.J. be Beer and R. Prins : J. Phys. Chem. 95, 123 (1991).

15) W. Niemann, B.S. Clausen and H. Topsøe : Catal. Lett. 4, 355 (1990).

16) S.P.A. Louwers and R. Prins : J. Catal. 133, 94 (1992).

17) S.P.A. Louwers and R. Prins : J. Catal. 139, 525 (1993).

18) S.M.A.M. Bouwens, F.B.M. van Zon, M.P. van Dijk, A.M. van der Kraan, V.H.J. de Beer, J.A.R. van Veen and D.C. Koningsberger : J. Catal. 146, 375 (1994).

19) Y. Okamoto, M. Kawano, T. Kawabata, T. Kubota and I. Hiromitsu : J. Phys. Chem. B 109, 288 (2005).
20) O. Kahn : "Molecular Magnetism” (VCH, 1993) Ch. 6.

21) 久保田岳志, 角野健史, 川端隆夫, 落合啓二, 広光一 郎, 岡本康昭: 触媒 48, 92 (2006).

22) Y. Okamoto, M. Kawano and T. Kubota : J. Chem. Soc., Chem. Commun. 1086 (2003).

23) J.V. Lauritsen, S. Helveg, E. Lægsgaad, I. Stegsgaard, B.S. Clausen, H. Topsøe and F. Besenbacher : J. Catal. 197, 1 (2001).

24) A. Travert, H. Nakamura, R.A. van Santen, S. Cristol, J.F. Paul and E. Payen : J. Am. Chem. Soc. 124, 7084 (2002).

25) 久保田岳志, 伊藤正貴, 岡本康昭: 触媒 49, 105 (2007).

26) 久保田岳志, 伊藤正貴, 田村健太, 岡本康昭 : 触媒 49, 525 (2007).

27) Y. Okamoto, A. Kato, Usman, K. Sato and T. Kubota : Chem. Lett. 34, 1258 (2005).

28) B. Hinnemann, J.K. Nørskov and H. Topsøe : J. Phys. Chem. B. 109, 2245 (2005).

29) Usman, T. Kubota, Y. Araki, K. Ishida and Y. Okamoto : J. Catal. 227, 523 (2004).

30) Usman, M. Takaki, T. Kubota and Y. Okamoto : Appl. Catal. A 286, 148 (2005).

31) Usman, T. Kubota and Y. Okamoto : Bull. Chem. Soc. Jpn. 79, 637 (2006).

32) J.A.R. van Veen, E. Gerkema, A.M. van der Kraan, P.A.J.M. Hendriks and H. Beens J. Catal. 133, 112 (1992).

33) Usman, T. Yamamoto, T. Kubota and Y. Okamoto : Appl. Catal. A 328, 219 (2007).

34) 岡本康昭: 触媒 50, 205 (2008). 